Anadolu Üniversitesi Bilim ve Teknoloji Dergisi C- Yaşam Bilimleri ve Biyoteknoloji

Anadolu University Journal of Science and Technology C- Life Sciences and Biotechnology

2018 - Volume: 7 Number: 1

Page: $12-19$

DOI : $10.18036 /$ aubtdc. 306292

Received: 14 April 2017 Revised: 28 September 2017 Accepted: 05 October 2017

\title{
LIPOLYTIC ACTIVITY OF LACTIC ACID BACTERIA ISOLATED FROM TURKISH PASTIRMA
}

\author{
Emine DİNÇER ${ }^{1, *}$, Merih KIVANÇ ${ }^{2}$ \\ ${ }^{1}$ Department of Nutrition and Dietetics, Faculty of Health Science, Cumhuriyet University, Sivas, Turkey \\ ${ }^{2}$ Department of Biology, Faculty of Science, Anadolu University, Eskişehir, Turkey
}

\begin{abstract}
Lipases are widely distributed in nature and catalyze the hydrolysis of mono, di and tri acyl glycerols to liberate free fatty acids and glycerol. Various microorganisms produce lipases either alone or together with esterase. Lipases form an important group of relevant enzymes and they were used in a variety of biotechnological fields such as food, pharmaceutical, detergent, textile and cosmetic industries. Lipases from lactic acid bacteria may contribute in the development of flavors in foods especially meat products. The goal of the present study is to investigate the ability to produce lipolytic enzymes lactic acid bacteria strains, which is selected as potential probiotics and isolated on pastırma samples in our laboratory to determinate the possibilities of using as starter cultures in pastırma production. Lipolytic activity of lactic acid bacteria isolated from pastırma has not been investigated up to now. The plate assay is performed to screening lipolytic activity of lactic acid bacteria isolates. In the study, three different growth medium tried and each medium contain tributyrin as a substrate. Using these methods, 50 strains of lactic acid bacteria isolated from Turkish pastirma are screened for the presence of lipolytic activity. Because of the analysis, the lipolytic activity is observed in 25 tested strains. Lactobacillus plantarum have highest lipolytic activity.
\end{abstract}

Key words: Lactic acid bacteria, Lipases, Lipolytic activity, Pastırma, Glycerol esterase

\section{PASTIRMADAN IZOLE EDILEN LAKTIK ASIT BAKTERILERINIIN LIPOLITIK AKTIVITESI}

\section{ÖZET}

Lipazlar doğada yaygın olarak bulunmaktadır ve mono, di, tri asil giliserollerin serbest yağ asitleri ve gliserole hidrolizini katalizlemektedirler. Çeşitli mikroorganizmalar lipazları tek başına ya da esterazlar ile birlikte üretmektedirler. Lipazlar ilgili enzimlerin önemli bir grubunu oluşturmaktadır ve gıda, ilaç, deterjan, tekstil ve kozmetik endüstrisi gibi çeşitli biyoteknolojik alanlarda kullanılmaktadırlar. Laktik asit bakteri lipazları gıdalarda özellikle de et ürünlerinde lezzet gelişimine katkı sağlayabilmektedir. Bu çalışmanın amacı, pastırma üretiminde starter kültür olarak kullanımlarını belirlemek için laboratuvarımızda pastırma örneklerinden izole edilmiş ve potansiyel probiyotik olarak seçilmiş laktik asit bakteri strainlerinin lipolitik enzimleri üretme yeteneklerini incelemektir. Pastırmadan izole edilen laktik asit bakterilerinin lipolitik aktivitesi şimdiye kadar araştırılmamıştır. Laktik asit bakteri izolatlarının lipolitik aktivitesinin taranması için plate analizleri gerçekleştirilmiştir. Çalışmada, 3 farklı gelişim ortamı denenmiştir ve her gelişim ortamı substrat olarak tributrin içermektedir. Bu yöntemler kullanılarak pastırmadan izole edilen 50 laktik asit bakteri straini lipolitik aktivite açısından taranmıştır. Analizler sonucunda 25 test straininde lipolitik aktivite gözlemlenmiştir. Lactobacillus plantarum en yüksek lipolitik aktiviteye sahiptir.

Anahtar kelimeler: Laktik asit bakterileri, Lipazlar, Lipolitik aktivite, Pastırma, Gliserol esteraz

\section{INTRODUCTION}

Lipases are an important group of relevant enzymes due to industrial potential and they are widely used in a variety of biotechnological fields such as food and dairy, pharmaceutical, detergent, agrochemical, oleo chemical, textile and cosmetic industries [1,2]. Lipolytic enzymes include lipases mainly catalyze the hydrolysis of water-insoluble long chain triglycerols and fatty acids and lipases performed an essential role

*Corresponding Author: edincer@cumhuriyet.edu.tr 
during fermentation and ripening steps of food elaboration $[3,4]$. Lipases have been isolated from many species of plants, animals, bacteria, fungi and yeast [5]. Lipolytic enzymes are found in bacteria [6, 7] and lipases from microbial origin, mainly bacterial and fungal are most commonly used in biotechnological applications due to easy extraction and easy cultivation of microbes [8,9]. Also, microbial enzymes are more stable than their corresponding plant and animal enzymes. Microbial lipases are widely diversified in their enzymatic properties and substrate specificity, which make them very attractive for industrial applications [5].

Lactic acid bacteria (LAB) are described as spherical or rod-shaped, gram positive, catalase-negative, nonsporulating, anaerobic, aerotolerant, and are mainly producers of lactic acid [10]. The early studies related to methods of detect lipase activity on lactic acid bacteria show that lactic acid bacteria have very low lipolytic activity [11]. However, a few recent research reported that some strains belong the lactic acid bacteria species such as $L$. plantarum have considerable lipolytic activity and lactic acid bacteria lipases are involved in the development of flavour and aroma in fermented meat products [12, 13]. Still, little information is available concerning lipases from lactic acid bacteria. Nowadays, lipolytic activity of lactic acid bacteria are among the most remarkable topics. Matthews et al [14] published a mini section according to the lipolytic activity of LAB in a review.

Pastırma (a traditional Turkish product) is one of the salted and dry cured meat products which are pasted with cemen (outside covered with a paste which makes it different from its counterparts) and is categorized as an intermediate moisture food [15]. Pastırma is highly regarded and very popular in most of the Middle East countries, it is usually consumed at breakfast without cooking. Although the production and consumption of pastırma is high, it is still produced traditionally and does not have any standard of production. Data in literature demonstrated that lactic acid bacteria, catalase positive cocci and yeasts were found resistant and able to survive during pastırma production $[15,16]$.

Lactic acid bacteria strains play a key role of maturation in fermented meat products. Of course, lactic acid bacteria strains can use as starter cultures have some important characteristic feature but this feature are not always adequate to make sure the sensory qualities, which are found in traditional meat product like pastirma or sausage. For this reason, extension activities are necessary like as lipolytic and proteolytic activity. Similarly, proteolysis and lipolysis activity contribute to the aroma and textural properties of pastirma. Traditionally lipolysis was thought to be related to bacterial lipase activity $[12,16]$. Some lactic acid bacterial strains have the ability to produce various lipolytic enzymes groups and generally these production in question are extracellular. As a general thing, biochemical and physicochemical parameters like temperature, $\mathrm{pH}$, and presence of lipids, inorganic salts, nitrogen and carbon source influence efficiency of lipase enzymes produced by lactic acid bacteria extensively [1].

The lipolytic activity of LAB has been more extensively researched in several areas of food production. Nevertheless, lipolytic activity of LAB isolated from pastırma has not been investigated up to now. The present work aims to screening for liypolytic activities of lactic acid bacteria representing the geniuses Lactobacillus, Enterococcus, Pediococcus, Leuconostoc and Weissella isolated from pastırma and aims to determinate the possibilities of using this strains industrially.

\section{MATERIAL AND METHODS}

\subsection{Microorganisms and Determination of Lipolytic Activity on Agar Media}

In this study, we investigated 50 lactic acid bacteria strains, previously isolated and identified, for their lipolytic ability. In total, 20 Lactobacillus plantarum, 2 Lactobacillus delbrueckii subsp. bulgaricus, 6 Lactobacillus sakei, 1 Lactobacillus reuteri 6 Enterococcus faecium, 1 Leuconostoc citreum, 1 Leuconostoc 
Dinçer and Kıvanç / Anadolu Univ. J. of Sci. and Technology C-Life Sci. and Biotech. 7 (1) - 2018

sp., 3 Weissella confusa, 2 Weissella hellenica, 3 Weissella viridescens, 4 Pediococcus acidilactici, 1 Pediococcus pentosaceus isolates previously isolated from Pastırma [17] are assessed. All of probiotic LAB strains isolated from meat products sources are obtained from Anadolu University, Faculty of Sciences, Department of Biology (Turkey). All lactic acid bacteria strains of meat products sources were identified using some phenotypic and genotypic tests as previously [17]. Three different medium (Tributyrin agar, Non-nutrient agar and Growth medium) prepared and three plate assay technique used for screening of lipolytic activity and each medium contains tributyrin as a substrate in plate [11]. By this way, each isolates are assessed according to the three different plate assay methods with all three growth medium. Three different analysis methods were performed simultaneously to elaborate the differences of the outcomes. Furthermore, assay was performed in triplicate for each strain and average values from three independent repetitions are accepted. Used growth medium and components are as follows.

Tributyrin agar (TBA) is consist of Peptone from meat $2.5 \mathrm{~g} / \mathrm{L}$; Peptone from casein $2.5 \mathrm{~g} / \mathrm{L}$; Yeast extract $3.0 \mathrm{~g} / \mathrm{L}$; Agar-agar $10.0 \mathrm{~g} / \mathrm{L}$. The medium was adjusted $\mathrm{pH} 7.0$, autoclaved and cooled to about $60 \mathrm{C}^{\mathrm{o}}$. Then $1 \mathrm{~mL}$ of neutral tributyrin $(1.0 \%$ [wt/vol]) was added and they were mixed. After that, $20 \mathrm{~mL}$ of medium was poured into each plastic petri dish [12].

Non-nutrient agar (NNA) composition per liter was Davis agar (Fluka, 79332) $12 \mathrm{~g}$ and 1 liter $1 \mathrm{M}$ phosphate buffer instead of distilled water. The medium was autoclaved and cooled to about $60 \mathrm{C}^{\mathrm{o}}$. Then $1 \mathrm{~mL}$ of neutral tributyrin $(1.0 \%$ [wt/vol] $)$ was added and they were mixed vigorously. After that, $20 \mathrm{~mL}$ of medium was poured into each plastic petri dish [18].

Growth medium (GM) contained (per liter) Peptone from meat $5.0 \mathrm{~g}$; Meat extract $3.0 \mathrm{~g}$; sodium chloride $4.0 \mathrm{~g}$ and Agar-agar $10.0 \mathrm{~g}$. The medium was adjusted $\mathrm{pH} 7.0$, autoclaved and cooled to about $60 \mathrm{C}^{\mathrm{o}}$. Then $10 \mathrm{~mL}$ Rhodamine B (1 mg. ml $\left.{ }^{-1}\right)$ solution $(1.0 \%$ [wt/vol] $)$ and $1 \mathrm{~mL}$ of neutral tributyrin $(1.0 \%$ [wt/vol]) was added and they were mixed vigorously. After that, $20 \mathrm{~mL}$ of medium was poured into each plastic petri dish [19].

\subsection{Agar Well Method}

LAB isolates were incubated in Man-Rogosa-Sharpe (MRS) broth and then $10^{10}$ cell concentration was obtained. Lipolytic activity was screening on three different agar medium (TBA, NNB and GM) from which well of $6 \mathrm{~mm}$ in diameter were cut into using a cork borer. For the lipolytic activity assay, $35 \mu$ lof overnight culture or $35 \mu \mathrm{l}$ of supernatant that is filter sterilized using pore size of $0.2 \mu \mathrm{m}$, inoculated into the wells. All plates were incubated at $30^{\circ} \mathrm{C}$ for 6 days. Lipolytic ability was detected on TBA and NNA as a clear zone around the wells and occurrence zones were measured each day of a week. Agar well method contained visualization of a clear zone on condition that tributyrin as substrates in the agar mediums. [11].

\subsection{Agar Spot Test}

LAB isolates were grown in MRS broth and cell suspensions were prepared. Then $10 \mu 1$ cell suspension fluids and $10 \mu 1$ of filter sterilized supernatant were spotted onto each agar plates. The plates were incubated at $30{ }^{\circ} \mathrm{C}$ for 6 days and zone of hydrolysis recorded each day of a week. [20].

\subsection{Agar Block Assay}

LAB isolates were grown on petri dishes containing MRS agar and incubated during $24 \mathrm{~h}$ for $30^{\circ} \mathrm{C}$. Then agar cultures cut the $6 \mathrm{~mm}$ in diameter using cork borer and have been inoculated previously prepared TBA, 
NNB and GM petri dishes. The plates were incubated $30^{\circ} \mathrm{C}$ for 6 days and zone of hydrolysis recorded each day of a week. On GM lipase activity was detected as a blue zone around the wells [18].

\section{RESULT}

In the present study, the medium composition and the test method have great importance in diagnosis of lipolytic activity. Because of the analysis, lipolytic activity of strains was changed according to the used medium. From the three different agar medium, TBA and other GM medium was showed positive results, whereas NNA was showed no positive results. In addition, used plate assay methods are important as much as used medium. None of strain was showed any lipolytic activity as measured by the agar well method and agar spot test. In the study found positive results with only agar block assay. The results could not be obtained with each three agar by agar well and agar spot methods.

In our study, L. plantarum strains, L.sakei, L. delbrueckii subsp. bulgaricus. E. faecium strains Leuconostoc sp. W. confusa, W. hellenica, W. viridescens and P. acidilactici, P. pentosaceus strains showed different lipolytic activity. L. plantarum-150 showed the highest activity on tributyrin agar. Because of the positive results cannot be obtained by the agar well and agar spot methods, only agar block method results show that Table 1.

Table 1. Results of preliminary screening of lipolytic activity on three different media with agar bloc assay $(+=$ weak activity (zone $<1.5 \mathrm{~cm}$ ); $++=$ medium activity (zone $1.5-2.0 \mathrm{~cm}$ ); $+++=$ strong activity (zone $>2.0 \mathrm{~cm}$ ); - = no activity (no zone).

\begin{tabular}{|c|c|c|c|}
\hline Lactic acid Bacteria & $\begin{array}{c}\text { Tributyrin } \\
\text { agar }\end{array}$ & Growth medium & $\begin{array}{c}\text { Non-nutrient } \\
\text { agar }\end{array}$ \\
\hline L. plantarum 16 & ++ & ++ & - \\
\hline L. plantarum 25 & ++ & + & - \\
\hline L. plantarum 150 & +++ & + & - \\
\hline L. plantarum 154 & + & + & - \\
\hline L. plantarum 159 & + & + & - \\
\hline L. plantarum 160 & ++ & ++ & - \\
\hline L. plantarum 161 & ++ & ++ & - \\
\hline L. plantarum 164 & ++ & + & - \\
\hline L. plantarum 166 & ++ & ++ & - \\
\hline L. plantarum 167 & ++ & ++ & - \\
\hline L. sakei 5 & ++ & + & - \\
\hline L. sakei 28 & + & + & - \\
\hline L.delbrueckii 156 & ++ & + & - \\
\hline E. faecium 97 & ++ & + & - \\
\hline E. faecium 99 & + & + & - \\
\hline E. faecium 299 & ++ & ++ & - \\
\hline E. faecium 168 & ++ & ++ & - \\
\hline E. faecium 169 & ++ & ++ & - \\
\hline E. faecium 277 & + & + & - \\
\hline L. citreum 220 & ++ & + & - \\
\hline P. pentosaceus 235 & ++ & + & - \\
\hline W.hellenica 27 & + & + & - \\
\hline W. hellenica 32 & ++ & ++ & - \\
\hline W.confusa 171 & ++ & ++ & - \\
\hline W. confusa 294 & + & + & \\
\hline
\end{tabular}


Dinçer and Klvanç / Anadolu Univ. J. of Sci. and Technology C-Life Sci. and Biotech. 7 (1) - 2018

\section{DISCUSSION}

In this study, plate assay methods were performed to determine lipolytic activity of $50 \mathrm{LAB}$ isolates. For the analysis, three different agar medium and three different assays were used. Using these methods, 50 strains of lactic acid bacteria, consisting of 20 L. plantarum, 2 L. delbrueckii subsp. bulgaricus, 6 L. sakei, 1 L. reuteri 6 E. faecium, 1 L. citreum, 1 Leuconostoc sp. 3 W. confusa, 2 W. hellenica, 3 W. viridescens, 4 $P$. acidilactici, $1 P$. pentosaceus were examined. As a result of the analysis, from the 50 strain tested, 25 strain were showed positive results on tributyrin agar and growth medium by the method of agar block assay (Table 1).

Various analysis methods and different medium for screening the lipolytic activity are available in the literatures. Plate assay methods widely used for this purpose [21]. Compared with the literature data, our results generally were similar with other authors' results. Kenneally et al [12] reported that, showed positive result on tributyrin agar but showed low lipolytic activity on spirit blue agar and spirit blue back fat agar. Kouker and Jaeger [19] also recorded the potential growth medium for plate assay technique used for screening of lipoliytic activity. Oterholm et al [22] in their study investigated lipolytic activity of lactic acid bacteria by agar well method and reported positive result on tributyrin agar. Fryer et al [18], recorded the potential non-nutrient agar for plate assay technique used for screening of lipoliytic activity, but our study that we have done non-nutrient agar was showed no positive results.

Another study reported that the intracellular and extracellular fragment of Leuconostoc mesenteroides $\mathrm{O} 257$, Lactobacillus plantarum $\mathrm{O} 236$, and Lactobacillus acidophilus $\mathrm{O} 177$ were able to hydrolyze tributyrin. $L$. plantarum O186, L. acidophilus O252, Enterococcus faecium $\mathrm{O} 174$ and $\mathrm{O} 426$, and Enterococcus faecalis Ov409 displayed liypolytic activity related to the intracellular fragment on tributyrin [23]. Lopes at al. [24] reported that lipolytic Lactobacillus strains isolated from fermented meat product on condition that tributyrin and olive oil as substrates in the agar medium. In addition, investigators take notice of tributyrin is a very convenient substrate in the first step as well as it is unspecific substrate.

Considering the studies in the literature, it is possible to say that there are many researches about lipolytic enzyme production ability of enterococci species. Lipolytic activity is frequently detected among enterococci [25-27]. In our study, E. faecium-97, E. faecium-299, E. faecium-168 and E. faecium-169 showed medium activity. El-Din et al. [27] reported lipolytic Enterococcus strains isolated from some dairy product types using different natural or synthetic substrates, including tributyrin. Simonova et al [1] described lipolytic enterococci isolated from meat products (sausage).

Davis et al. [28] reported some strains of Oenococcus oeni have esterolytic and/or lipolytic activities, in the maintime another studies reported no lipase activities in 32 strains of Lactobacillus, 2 strains of Leuconostoc, and 3 strains of Lactococcus isolated in wine [10, 29]. Baur et al. [30] in their study investigated lipolytic activity of microorganisms isolated from raw milk and they reported that two enzymatically active LAB isolates. Similarly, as a result of the another study evaluating lipase activity of bacterial strains isolated artisanal raw ewe's milk cheese investigators reported that lactic acid bacteria displayed very minor enzymatic ability [2].

Due to lipolytic enzyme types are in general extracellular or relevant to whole cells, lactic acid bacteria have the potential to change the lipid context of the meat products. Karslioğlu et al. [31] evaluated the effects of two different commercial starter culture mixes (including Lactobacillus sake, Pediococcus pentosaceus and other starters) on the lipolytic changes of fermented sausages manufactured with turkey meat and they 
reported fermented sausage groups produced with starter culture had lower thiobarbituric acid and free fatty acid values in comparison with the control groups.

Lipase enzymes produced by useful bacteria found naturally in meat products and their activity are needed to for product quality. Moreover, lipolysis as technologically relevant property is usually determined to evaluate the strain suitability as starter culture in meat productions, due to their contribution to the flavour development. Maturation progress in fermented meat products and dairy products take a long time and this condition making it possible for even strains with low lipolytic activity are effective. In this respect, lactic acid bacterial strains have a great potential for flavour formation in such products and lipolytic activity of lactic acid bacteria has been very attentive in recent years [24].

\section{CONCLUSION}

Lipases acquined much attention since their ability to involve in a wide variety of reactions and these enzymes are also having roles in different industrial applications like food industry. Because lipases are located extracellularly or are associated with the whole cells, lipolytic activity of LAB have the potential to influence aroma and textural properties of the pastırma. The aim of this study was the assessed of lipolytic activity produced by pastırma inherent microbiota and investigation has revealed the potentials of lactic acid bacteria on lipase. Lipolytic activity of lactic acid bacteria isolated from pastırma has not investigated up to now and in our study the lipolytic activity was observed in 25 tested strains. The reported lipolytic activity of our stains can be of particular attention because of with the existing activity could derivable some new advances and advantages in food industry. In addition, activity measurements by plate assays is rather qualitative method and our study include only qualitative results. Therefore it seems additional studies necessary for the usage in food industry.

\section{ACKNOWLEDGMENTS}

This project was financially supported by "Anadolu University Council of Research Project Fund" (Project No: 41020) for their support of chemicals and instruments.

\section{REFERENCES}

[1] Simonova M, Sirotek K, Marounek M, Laukova A. Lipolytic activity of potential probiotic Enterococci and additive Staphylococci. Acta Vet Brno 2008; 77: 575-580.

[2] Ozturkoglu-Budak S, Wiebenga A, Bron PA, de Vries RP. Protease and lipase activities of fungal and bacterial strains derived from an artisanal raw ewe's milk cheese. Int J Food Microbiol 2016; 237: 17 27.

[3] Esteban-Torres M, Mancheno JM, de las Rivas B, Munoz R. Characterization of a halotolerant lipase from the lactic acid bacteria Lactobacillus plantarum useful in food fermentations. LWT- Food Sci Technol 2015; 60: 246-252.

[4] Esteban-Torres M, Mancheno JM, de las Rivas B, Munoz R. Production and characterization of a tributyrin esterase from Lactobacillus plantarum suitable for cheese lipolysis. J Dairy Sci 2014; 97 (11): 6737-6744.

[5] Ray A. Application of Lipase in Industry. Asian J Pharm Technol 2012; 2 (2): 33-37. 
Dinçer and Kıvanç / Anadolu Univ. J. of Sci. and Technology C-Life Sci. and Biotech. 7 (1)-2018

[6] Saxena RK, Sheoran A, Giri B, Davidson WS. Purification strategies for microbial lipases. J Microbiol Meth 2003; 52: 1-18.

[7] Gupta R, Gupta N, Rathi P. Bacterial lipases: an overview of production, purification and biochemical properties. Appl Microbiol Biot 2004; 64: 763-781.

[8] Saxena RK, Ghosh PK, Gupta R, Davidson SW, Bradoo S. Microbial lipases potential biocatalysts for the future industry. Curr Sci 1999; 77: 101-115.

[9] Ülker S, Alpay Karaoğlu Ş. Purification and characterization of an extracellular lipase from Mucor hiemalis f. corticola isolated from soil. J Biosci Bioeng 2012; 114: 385-390.

[10] Rosario Munoz R, Moreno-Arribas MV, Rivas B. Lactic Acid Bacteria. In: Carrascosa AV, Munoz R and Gonzales R, editors. Molecular Wine Microbiology. San Diego, CA, USA: Academic Press, 2011. pp. 191-216.

[11] Vogel RF, Gaier W, Hammes WP. Expression of the lipase gene from Staphylococcus hyicus in Lactobacillus curvatus Lc2-c. FEMS Microbiol Lett 1990; 69: 289-292.

[12] Kenneally PM, Leuschner RG, Arendt EK. Evaluation of the lipolytic activity of starter cultures for meat fermentation purposes. J Appl Microbiol 1998; 84: 839-846.

[13] Montel MC, Masson F and Talon R. Bacterial role in flavour development. Meat Sci 1998; 49: 111123.

[14] Matthews A, Grimaldi A, Walker M, Bartowsky E, Grbin P, Jiranek V. Lactic acid bacteria as a potential source of enzymes for use in vinification. Appl Environ Microb 2004; 70: 5715-5731.

[15] Kilic B. Current trends in traditional Turkish meat products and cuisine. LWT-Food Sci Technol 2009; 42: 1581-1589.

[16] Ozturk I. Presence, changes and technological properties of yeast species during processing of pastirma, a Turkish dry-cured meat product. Food Control 2015; 50: 76-84.

[17] Dincer E, Kivanc M. Characterization of lactic acid bacteria from Turkish Pastirma. Ann Microbiol 2012; 62(3): 1155-1163.

[18] Fryer TF, Reiter B, Lawrence RC. Lipolytic activity of lactic acid bacteria. J Dairy Sci 1967; 50: 388389.

[19] Kouker G, Jaeger KE. Specific and sensitive plate assay for bacterial lipases. Appl Environ Microb 1987; 53: 211-213.

[20] González L, Sandoval H, Sacristán N, Castro JM, Fresno JM, Tornadijo ME. Identification of lactic acid bacteria isolated from Genestoso cheese throughout ripening and study of their antimicrobial activity. Food Control 2007; 18: 716-722. 
Dinçer and Kıvanç / Anadolu Univ. J. of Sci. and Technology C-Life Sci. and Biotech. 7 (1)-2018

[21] Lanka S, Latha JNL. A short review on various screening methods to isolate potential lipase producers: lipases-the present and future enzymes of biotech industry. Int J Bio Chem 2015; 9 (5): 207-219.

[22] Oterholm A, Ordal ZJ, Witter LD. Glycerol ester hydrolase activity of lactic acid bacteria. Appl Microbiol 1968; 16 (3): 524-527.

[23] Katz M, Medina R, Gonzales S, Oliver G. Esterolytic and lipolytic activities of lactic acid bacteria isolated from ewe' s milk and cheese. J. Food Protect 2002; 65 (12): 1997-2001.

[24] Lopes MFS, Leitao AL, Regalla M, Marques JJF, Carrondo MJT, Crespo MTB. Characterization of a highly thermostable extracellular lipase from Lactobacillus plantarum. Int J Food Microbiol 2002; 76 : 107-115.

[25] Kar M, Ray L, Chattopadhyay P. Isolation and identification of alkaline thermostable lipase producing microorganism and some properties of crude enzyme. Ind J Exp Biol 1996; 34: 535-538.

[26] Rosenstein R, Götz F. Staphylococcal lipases: Biochemical and molecular characterization. Biochimie 2000; 82: 1005-1014.

[27] El-Din BB, El-Soda M, Ezzat N. Proteolytic, lipolytic and autolytic activities of enterococci strains isolated from Egyptian dairy products. Lait 2002; 82: 289-304.

[28] Davis CR, Wibowo D, Fleet GH, Lee TH. Properties of wine lactic acid bacteria: their potential enological significance. Am J Enol Vitic 1988; 39: 137-142.

[29] Herrero M, Mayo B, Gonzalez B and Suarez, JE. Evaluation of technologically important traits in lactic acid bacteria isolated from spontaneous fermentations. J Appl Bacteriol 1996; 81: 565-570.

[30] Baur C, Krewinkel M, Kranz B, von Neubeck M, Wenning M, Scherer S, Stoeckel M, Hinrichs J, Stressler T, Fischer L. Quantification of the proteolytic and lipolytic activity of microorganisms isolated from raw milk. Int Dairy J 2015; 49: 23-29.

[31] Karslioğlu B, Ensoy Çiçek Ü, Kolsarici N, Candoğan K. Lipolytic Changes in Fermented Sausages Produced with Turkey Meat: Effects of Starter Culture and Heat Treatment. Korean J Food Sci An 2014; 34(1): 40-48. 